の方法て照射しているようである. 全国的にみて症例数 あ少く，線量測定，線量撞価も未解決の部分もあり，施 設間で統一できる項目（基準点，その厚みの取り方，線 量モ二タする点，その方法等）は話し合って基準を作り 早く治療評価を出して確立された照射法になるととを望 む:

\section{RI-3 放射性医薬品他}

座長 本田 稔 (住友病院)

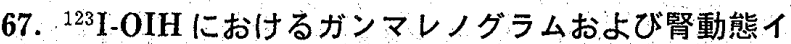
$x-シ 3$

患応義熟大学病院

放射線業務管理室 (RI 部門)

○山本忠利・岡野義幸・北川五十雄 三宮敏和・清水正勝

レノグラムには，従来より ${ }^{131} \mathrm{I}-\mathrm{O} I H$ が広く使用され

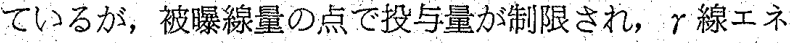
ルギーが比較的高いためシンチカメラのイメージングに は不適当である。

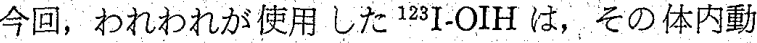
態も ${ }^{131} \mathrm{I}$-OIH とほぼ等しいため，レノグラムはその機 能を反映していると思われる。また，被曝線量が少なく 比較的大量投与が可能なため，レノグラムと同時に腎動 態イメージが得られた。また，データ処理装置を用いて 区域レノグラムを作成することにより，盘実質障害と腎 孟の機能障害を判別するのに有用であると思われる。

\section{8. ${ }^{123}$ I 摄取率測定简便化の検討}

近畿大学医学部附属病院中央放射線部

○黑田晃代・坂下太郎・大開敬三

甲状腺検査には今日，エネルギーや被懪低減等の優位 性を持つ I-123 が I-131 に代わり使用されるようにな ってきた。しかし，短半減期核種りえに，患者摄取率測 定毎に標準線を測定しなければならないという苦点が生 じた，そこで(1)経時的に計測して得た多数の值を平均し

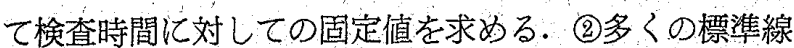
源計数值から指数回帰式を求めてそれ亿時間を代入して 算出する、(3)各検定カプセル毎に一度実測して(2)を補正 するという3つの標準線源計数測定の簡便法を考案し, その有用性を礁認した。結果ししては(3)が最適だったが， どれあ相関的によい值が得られているのでどの方法を取 っても問題はないだるうと考えられる。

\section{I-123 による甲状腺検査法}

横浜市立大学医学部病院
○氏家盛通・野沢武夫・桜去 榑 渡边好 。三谷康博

公立藤田総合病院 山館節男

ヨードによる甲状腺の検查は一般に広く実施されてい る検查であるが数年前より I-131 とスキャナの組合せよ り【-123とカメラによる方法が被嚗線量6少く画質の良 いシンチグラムが得られる利点があり一般的に実施され るようになっだ。甲状腺のヨード摂取率は他の臓器と異 り $1 \%$ に满たない6の汃ら $100 \%$ 近いものまであり同一 の条件での撮像は困難である，摂取率の経時変化之減袁 とより摂取量の多し投与後 $4 \sim 6$ 時間後に 3 時間の㩒取 率をむとにした条件表により一定の条件のもとで画質の 良しシンチグラムが效率的に得られるようになった。 の方法は装置，フィルムの種類，サイズ，検查人数，投 与量が䡒っても換算流数が分れば他でも応用が可能であ b.

\section{0. 乳幼児の甲状腺 ${ }^{123}$ I 摂取率検査法}

神奈北県立しども医療センター

○西尾誠示

${ }^{123}$ I 捸取率測定法について乳幼児に適した方法を検討 した.

(1)シンチグラムで乳幼児の甲状腺サイズを計測した。

(2)乳约児用のファントム $(8 \mathrm{~cm} \phi), \mathrm{B}$ フィル夕 $(5 \times 5)$ を試作した。

(3) 3 種のコリメータのフィールドを比較.

(4)各々のコリメータ，Bフィルタを用い，模擬甲状腺 を測定し，比較した。

(5)臨床にて，3者の方法（乳奻児法，從来の方法，成 人の方法）を比較した。

〔結果】 1. 標準】ァントムは乳幼児の頸部を考慮し たものが望ましけ。

2.Bフィルタは甲状腺のサイズよりやや大きめ程度 が良い。

3.コリメータは径の小さいものか適当である。

4. 低年秢罗任よ゙使用器材による誤差が増える。

5. 乳幼児に対する検查の標準化を計るべきである。

71. ${ }^{201} \mathrm{~T} 1$ 甲状腺シンチグラフィーにおける early scan ならびに delayed scan の基礎的検討 北海道大学医学部附属病院放射線部

○勝浦秀則・荒井博史・表 英彦 高橋典子・鈴木幸太郎 北海道大学医学部附属病院放射線科 古館正従

[目的〕 ${ }^{201} \mathrm{~T}$ 甲状腺シンチグラフィで early scan お 